\title{
ANALISIS PERLINDUNGAN HUKUM BAGI KREDITUR DALAM PEMINJAMAN UANG BERBASIS TEKNOLOGI FINANSIAL (KOINWORK)
}

\author{
Sawitri Yuli Hartati S., ${ }^{1}$ M. Rusdi Daud, ${ }^{2}$ dan Nurohmat ${ }^{3}$ \\ Fh.sawitri@gmail.com,rusdi3daud@gmail.com,nurohmat_fhumj@gmail.com \\ Fakultas Hukum Universitas Muhammadiyah Jakarta \\ Jl. KH. Ahmad Dahlan, Cirendeu, Ciputat, Tangerang Selatan, Banten.
}

\begin{abstract}
Abstrak
Kegiatan peminjaman uang berbasis teknologi finansial, hubungan hukum hanya terjadi antara Kreditur dengan Penyelenggara layanan peminjaman uang berbasis teknologi finansial dan antara Kreditur dengan Debitur. Hal yang demikian menempatkan Penyelenggara layanan peminjaman tidak memiliki hubungan hukum dengan Debitur, sehingga Penyelenggara layanan peminjaman tidak memiliki tanggungjawab hukum manakalah terjadi gagal bayar oleh Debitur. Penelitian ini dimaksudkan untuk meneliti hal dimaksud, khususnya tentang perlindungan dan kepastian hukum bagi Kreditur dalam kegiatan peminjaman uang berbasis teknologi finansial. Metode penelitian ini menggunakan tipe penelitia diskriptif kualitatif. Hasil penelitian menyimpulkan bahwa hubungan hukum PT. Lunaria Annua Teknologi (KoinWorks) selaku penyelenggara layanan peminjaman sebatas dengan Kreditur, bukan dengan Debitur. Adapun perlindungan hukum bagi kreditur manakalah terjadi gagal bayar oleh Debitu, telah dijamin oleh POJK Nomor 77/POJK.01/2016 tentang Layanan Pinjam Meminjam Uang berbasis Teknologi Informasi dan POJK Nomor 1/POJK.07/2013 tentang Perlindungan Konsumen Sektor Jasa Keuangan.
\end{abstract}

Kata Kunci: Perlindungan Hukum, Peminjman Uang, Teknologi Finansial, dan Kreditur.

\footnotetext{
${ }^{1}$ Dosen Tetap pada Fakultas Hukum Universitas Muhammadiyah Jakarta.

2 Dosen Tetap pada Fakultas Hukum Universitas Muhammadiyah Jakarta.

${ }^{3}$ Mahasiswa program Srajana pada Fakultas Hukum Universitas Muhammadiyah Jakarta.
} 


\title{
AL-QISTH LAW REVIEW \\ VOL 5 NO. 1 (2021)
}

\begin{abstract}
In Financial technology-based money lending activities, legal relations only occur bertween the Cretidor and the Provider of financial technology-based money lending services and between the Creditor and the Debtor. This places the lending service provider not having a legal relationship with the debtor, so the lending service provider has no legal responsibility in the event of a default by the debtor. This study is intended to examine this matter, especially regarding legal protection and certainty for creditors in financial technology-based money lending activities. This research method uses a qualitative descriptive type of research. The results of the study concluded that the legal relationship of PT. Lunaria Annua Teknologi (KoinWorks) as the provider of lending services is limited to creditors, not debtors. As for legal protection for creditors in the event of default by the debtor, it has been guaranteed by POJK Number 77/POJK.01/2016 concerning Information Technology-based Lending and Borrowing Services and POJK Number 1/POJK.07/2013 concerning Consumer Protection in the Financial Services Sector.
\end{abstract}

Keywords: Legal Protection, Money Lending, Financial Technology, and Creditors.

\section{A. PENDAHULUAN}

\section{a. Latar Belakang Masalah}

Sesuai dengan laju pertumbuhan ekonomi dan gerak pembangunan, lembaga keuangan tumbuh dengan berbagai alternatif jasa yang ditawarkan. Lembaga keuangan yang merupakan lembaga perantara dari pihak yang kelebihan dana (surplus of funds) dengan pihak yang kekurangan dana (lack of funds) yang memiliki fungsi sebagai perantara keuangan masyarakat (financial intermediary). Lembaga keuangan, sebagaimana halnya suatu lembaga atau institusi pada hakikatnya berada 


\section{AL-QISTH LAW REVIEW \\ VOL 5 NO. 1 (2021)}

dan ada di tengah-tengah masyarakat. Lembaga yang merupakan organ masyarakat merupakan "sesuatu" yang keberadaannya adalah untuk memenuhi tugas sosial dan kebutuhan khusus bagi masyarakat. Berbagai jenis lembaga ada dan dikenal masyarakat yang masing-masing mempunyai maksud dan tujuan dari tiap lembaga yang bersangkutan (Imaniyati, 2010).

Perkembangan perekonomian Indonesia salah satunya adalah bertopang pada sektor perbankan yang ada di Indonesia. Bank adalah sebagai salah satu lembaga keuangan yang fungsi utamanya sebagai penghimpun dana dan menyalurkan dana masyarakat. Perbankan nasional berfungsi sebagai sarana pemberdayaan masyarakat dan seluruh kekuatan ekonomi nasional, terutama pengusaha kecil, menengah, dan koperasi. Oleh sebab itu perbankan Indonesia sebagai agen pembangunan (agent of development) yaitu sebagai lembaga yang bertujuan guna mendukung pelaksanaan pembangunan nasional dalam rangka pemerataan pembangunan dan hasil-hasilnya, pertumbuhan ekonomi dan stabilitas nasional ke arah peningkatan taraf hidup rakyat banyak (Djumhana, 2012).

Hal ini diatur di dalam Pasal 1 angka 2 Undang-Undang Nomor 10 Tahun 1998 Perubahan Atas Undang-Undang Nomor 7 Tahun 1992 tentang Perbankan (selanjutnya disebut Undang-Undang Perbankan) bahwa bank adalah badan usaha yang menghimpun dana dari masyarakat dalam bentuk simpanan dan menyalurkannya kepada masyarakat dalam 


\section{AL-QISTH LAW REVIEW \\ VOL 5 NO. 1 (2021)}

bentuk kerdit dan atau bentuk lainnya dalam rangka meningkatkan taraf hidup rakyat banyak. Bank yang merupakan lembaga intermediasi keuangan (financial intermadiary) yaitu kegiatan pengalihan dana dari pihak yang kelebihan dana (unit ekonomi surplus) kepada pihak yang kekurangan dana (unit ekonomi defisit). Baik pihak kelebihan dana (unit ekonomi surplus) maupun pihak yang kekurangan dana (unit ekonomi defisit) dapat berupa badan usaha, lembaga pemerintah, atau perorangan (Muhammad dan Murniati, 2000).

Bisnis yang dijalankan dalam kegiatan perbankan merupakan kegiatan bisnis yang penuh resiko (full risk business) karena aktivasinya sebagian besar mengandalkan dana titipan masyarakat. Besarnya peran perbankan dalam kegiatan perekonomian harus didukung dengan peraturan yang kuat. Hal tersebut sebagai upaya mewujudkan perbankan yang sehat (Zaini dan Febriansyah, 2014).

Akan tetapi, timbul permasalahan terhadap pemerataan layanan perbankan di Indonesia dalam melaksankan tugasnya untuk meningkatkan taraf hidup rakyat banyak. Hal ini terjadi karena berdasarkan letak geografis Indonesia yang merupakan negara kepulauan, jangkauan masyarakat terhadap layanan perbankan menjadi sulit karena perbankan itu sendiri tidak merata. Layanan perbankan hanya tertumpuk di pusat kota saja, kurang menyentuh masyarakat yang ada di pelosok daerah, Hal ini dapat menyebabkan terjadinya kesenjangan kesejahteraan 


\section{AL-QISTH LAW REVIEW \\ VOL 5 NO. 1 (2021)}

di Indonesia akibat tidak meratanya pembangunan perekonomian nasional.

Sulitnya sebagian besar masyarakat daerah untuk mendapatkan layanan perbankan menjadikannya fakta mengenai tingginya jumlah penduduk yang belum tersentuh layanan perbankan (unbanked people) (Lyman, Ivatury \& Stacehn, 2008). Kondisi demikian terutama terjadi di negara-negara berkembang. Di Indonesia, angka warga negara usia dewasa baik yang belum mengenal, menggunakan, atau memiliki akses pada layanan perbankan tergolong masih tinggi (Bank Indonesia, 2013).

Berdasarkan hasil survei Bank Dunia, kurang dari 50\% penduduk Indonesia memiliki rekening bank pada institusi keuangan formal (bank) dan hanya $17 \%$ dari penduduk yang mempunyai akses kredit. Lebih jauh, hasil survei rumah tangga yang dilakukan Bank Indonesia pada tahun 2010 menunjukkan bahwa 62\% rumah tangga tidak memiliki tabungan sama sekali. Jumlah kepemilikan rekening masyarakat Indonesia dinilai masih rendah bahkan se-Asean. Salah satu faktor yang menjadi penyebab terbatasnya layanan perbankan ke masyarakat diseluruh pelosok adalah terbatasnya infrastruktur karena kondisi alam Indonesia yang berkepulauan. Masyarakat sendiri masih merasakan hambatan dalam memperoleh layanan jasa keuangan formal dari perbankan. Selain keterbatasan infrastruktur lembaga keuangan dimaksud, juga disebabkan rendahnya penghasilan sehingga pendapatan yang diterima penduduk desa lebih banyak digunakan untuk konsumsi. Berdasarkan hasil survei 


\section{AL-QISTH LAW REVIEW \\ VOL 5 NO. 1 (2021)}

Bank Dunia 79\% masyarakat yang tidak memiliki tabungan karena tidak memiliki uang. Namun demikian, masyarakat berpendapatan rendah adalah active money managers yang sangat membutuhkan akses keuangan terhadap lembaga keuangan khususnya perbankan. Selain itu, rendahnya pemahaman masyarakat tentang keuangan (financial literacy) dan belum tersedianya produk yang sesuai untuk kelompok masyarakat kecil menambah rumit persoalan (Wibowo, 2013).

Seiring dengan perkembangan masa di era globalisasi ini, apapun aktivitas masyarakat tidak akan terlepas dari bantuan teknologi. Begitu pula pada lembaga keuangan yang kini mulai bergeser pada lembaga keuangan berbasis teknologi. Salah satu kemajuan dalam bidang keuangan saat ini adanya adaptasi Teknologi Finansial.

Teknologi finansial merupakan implementasi dan pemanfaatan teknologi untuk peningkatan layanan jasa perbankan dan keuangan yang umumnya dilakukan oleh perusahaan rintisan (startup) dengan memanfaatkan teknologi software, internet, komunikasi, dan komputasi terkini. Konsep ini yang mengadaptasi perkembangan teknologi yang dipadukan dengan bidang finansial sehingga bisa menghadirkan proses transaksi keuangan yang lebih praktis, aman serta modern. Bentuk dasar teknologi finansial antara lain Pembayaran (digital wallets, Peer to Peer payments), Investasi (equity crowdfunding, Peer to Peer Lending), Pembiayaan (crowdfunding, micro-loans, credit facilities), Asuransi (risk management) (Iman, 2016). 


\section{5 \\ AL-QISTH LAW REVIEW \\ VOL 5 NO. 1 (2021)}

Kemunculan perusahaan-perusahaan keuangan dalam bidang penyedia layanan pinjam meminjam uang berbasis teknologi informasi yang semakin mendapatkan perhatian publik dan regulator yakni Otoritas Jasa Keuangan (OJK) dan Bank Indonesia. Hal tersebut tertuang dalam Peraturan Otoritas Jasa Keuangan Nomor 77/POJK.01/2016 tentang Layanan Pinjam Meminjam Uang Berbasis Teknologi Informasi. Pada POJK tersebut mengatur tentang layanan pinjam meminjam uang berbasis teknologi informasi. Layanan ini merupakan suatu terobosan di mana banyak masyarakat Indonesia yang belum tersentuh layanan perbankan (unbanked people) akan tetapi sudah melek akan teknologi. Layanan pinjam meminjam uang berbasis teknologi finansial menjadi salah satu solusi terbatasnya akses layanan keuangan di tanah air dan mewujudkan inklusi keuangan melalui sinerginya dengan institusi-institusi keuangan dan perusahaan-perusahaan teknologi lainnya (Wijaya, 2016).

Indonesia memiliki lebih dari 57 juta pelaku usaha mikro, namun, hanya satu persen dari usaha tersebut yang dapat berkembang menjadi UKM berdaya saing. Indonesia memiliki kesempatan memanfaatkan teknologi finansial untuk mengisi kekosongan dana, mempengaruhi ekonomi dan memberi dampak positif bagi jutaan orang di negara ini. Teknologi finansial adalah sarana baru yang dapat digunakan untuk mempercepat inklusi keuangan nasional (Audriene, D., Nababan. C. N., 2016). Kemudahan-kemudahan yang ditawarkan dalam teknologi finansial membuat tumbuh banyak perusahaan teknologi finansial di Indonesia. Apabila melakukan pinjam meminjam uang dalam bank 


\section{AL-QISTH LAW REVIEW \\ VOL 5 NO. 1 (2021)}

konvesional, bank memiliki lebih banyak persyaratan yang harus dipenuhi sehingga membutuhkan waktu yang cukup lama untuk pencairan dana. Sebaliknya dengan layanan pinjaman meminjam uang berbasis teknologi finansial ini menjual kecepatan dan kemudahan di era digital. Ketika sebuah penyedia layanan pinjam meminjam uang berbasis teknologi finansial telah memiliki Kreditur, maka mereka siap memberikan pinjaman. Langkah yang perlu diikuti biasanya tertera lengkap di website, terutama karena aktivitas layanan pinjam meminjam uang berbasis teknologi finansial mayoritas dilakukan secara online.

Penyedia layanan pinjam meminjam uang berbasis teknologi finansial merupakan sebuah Penyelenggara. Tujuan pemanfaatan teknologi informasi dan transaksi elektronik sebagaimana diatur dalam Pasal 4 Undang-Undang Republik Indonesia Nomor 11 Tahun 2008 tentang Informasi dan Transaksi Elektronik:

1. mencerdaskan kehidupan bangsa sebagai bagian dari masyarakat informasi dunia;

2. mengembangkan perdagangan dan perekonomian nasional dalam rangka meningkatkan kesejahteraan masyarakat;

3. meningkatkan efektivitas dan efisiensi pelayanan publik;

4. membuka kesempatan seluas-luasnya kepada setiap orang untuk memajukan pikiran dan kemampuan di bidang penggunaan dan pemanfaatan Teknologi Informasi seoptimal mungkin dan bertanggung jawab; dan 


\section{AL-QISTH LAW REVIEW \\ VOL 5 NO. 1 (2021)}

5. memberikan rasa aman, keadilan, dan kepastian hukum bagi pengguna dan penyelenggara Teknologi Informasi.

Pelaksanaan layanan pinjam meminjam uang berbasis teknologi finansial diperlukan adanya regulasi yang mengaturnya karena teknologi finansial termasuk dalam mikroprudensial sehingga kegiatannya akan senantiasa di awasi oleh Otoritas Jasa Keuangan (selanjutnya disebut OJK). Sistem pengawasan secara mikroprudensial maksudnya adalah OJK memiliki kewenangan yang lebih mengarah kepada analisis perkembangan individu lembaga keuangan. Oleh karena itu, kegiatan yang dilakukan penyelanggara layanan pinjam meminjam uang berbasis teknologi finansial harus tetap dalam koridor hukum pengawasan OJK, sebagaimana diatur dalam Pasal 37 Peraturan Otoritas Jasa Keuangan Nomor 77/POJK.01/2016 tentang Layanan Pinjam Meminjam Uang berbasis Teknologi Informasi yang telah menegaskan bahwa: "Penyelenggara wajib bertanggung jawab atas kerugian Pengguna yang timbul akibat kesalahan dan/atau kelalaian, Direksi, dan/atau pegawai Penyelenggara."

Pada prakteknya, kemunculan perusahaan-perusahaan teknologi finansial yang telah terdaftar dan diawasi OJK, juga menimbulkan permasalahan hukum yang baru pula. Sebagai contoh penulis hendak memberikan salah satu contoh perusahaan yaitu PT. Lunaria Annua Teknologi (KoinWorks). Dalam mekanismenya KoinWorks adalah sebagai Penyelenggara layanan pinjam meminjam uang berbasis teknologi 


\section{AL-QISTH LAW REVIEW \\ VOL 5 NO. 1 (2021)}

informasi yang menyediakan wadah bagi Kreditur untuk menyalurkan dana kepada Debitur dan begitupun sebaliknya.

Sebagaimana dikutip dari laman https://www.koinworks.com kegiatan Penyelenggara dalam Penyelenggaraan layanan pinjam meminjam uang berbasis teknologi finansial sebagai wadah bagi kegiatan seperti pinjam meminjam uang pada umumnya. Pemberi Pinjaman berkudukan sebagai kreditur dan Penerima Pinjaman sebagai debitur. Keduanya memiliki hubungan hukum sebagaimana pinjam meminjam pada umumnya. Penyelenggara, selain sebagai pihak yang menyediakan ruang eksklusif bagi kegiatan pinjam meminjam uang secara online juga sebagai pihak yang menyeleksi, menganalisis, dan menyetujui aplikasi pinjaman yang diajukan oleh Debitur agar menghasilkan pendanaan yang berkualitas untuk ditawarkan kepada para Kreditur, sehingga Kreditur hanya bisa memilih Debitur berdasarkan portofolio analisis yang ditawarkan oleh Penyelenggara.

KoinWorks menarik minat Kreditur dengan adanya perolehan pengembalian atas nilai yang diinvestasikan atau dipinjamkan melalui Koinworks kepada Debitur kemudian ditambah dengan bunga dengan jadwal pembayaran kepada Kreditur pada waktu yang telah disepakati. Kreditur dapat dengan bebas memberikan pinjaman melalui KoinWorks tanpa ada batasan apapun. KoinWorks menggunakan skema credit scoring yang memberikan grade ke masing-masing tipe Debitur, dari grade A hingga E di mana masing-masing grade dipecah lagi ke dalam lima tingkatan, 


\section{AL-QISTH LAW REVIEW \\ VOL 5 NO. 1 (2021)}

mulai dari A1 sebagai grade yang tertinggi hingga E5 yang terendah. Setiap grade memiliki suku bunga yang berbeda-beda. Resiko yang tinggi akan menghasilkan bunga yang lebih tinggi pula. KoinWorks dengan tegas tidak melakukan penjaminan sepenuhnya kepada Kreditur yang telah menyalurkan dananya melalui KoinWorks karena hal tersebut merupakan resiko yang mungkin terjadi apabila melakukan investasi atau memberikan pinjaman kepada pihak Debitur meskipun melalui KoinWorks.

Berdasarkan contoh tersebut, yang dilakukan Penyelenggara (KoinWorks) adalah hanya menyediakan tempat bagi Pemberi dan Penerima Pinjaman. Penyelenggara bukan sebagai pihak dalam perjanjian pinjam meminjam uang yang dilakukan oleh Kreditur dan Debitur sehingga Penyelenggara tidak memiliki tanggung jawab atau kewajiban dalam perjanjian pinjam meminjam secara online tersebut apabila terjadi gagal bayar oleh Debitur. Ketiadaan hubungan hukum antara Penyelenggara dengan Pengguna layanan pinjam meminjam tersebut menimbulkan konsekuensi hukum. Khususnya bagi Kreditur tidak dapat mengajukan tuntutan hukum kepada Penyelenggara apabila Kreditur mengalami kerugian sebagai akibat tindakan Penyelenggara dalam Penyelenggaraan layanan pinjam meminjam uang berbasis teknologi finansial.

\section{b. Rumusan Masalah}

Secara khusus peneltian ini dimaksudkan untuk menjawab 2 (dua) hal: Pertama, bagaimana perlindungan hukum bagi kreditu dalam pinjam 


\section{AL-QISTH LAW REVIEW \\ VOL 5 NO. 1 (2021)}

meminjam uang berbasis teknologi finansial; dan, Kedua, apakah praktik yang terjadi dilapangan sudah sesuai dengan ketentuan yang berlaku.

\section{c. Metode Penelitian}

Tipe yang digunakan adalah diskriptif kualitatif yang dimaksudkan untuk menggambarkan melalui sosialisasi dengan model diskusi yang telah dikembangkan dan disesuaikan dengan kondisi PT. KoinWork tersebut terhadap perlindungan hukum bagi kreditur dalam pinjam meminjam uang yang berbasis teknologi finansial. Data yang dikumpulkan akan dianalisis secara kualitatif yang selanjutnya diinterprestasikan dan disajikan dalam bentuk uraian atau naratif yang kemudian dilakukan interprestasi teoritik untuk memberikan makna terhadap hasil penelitian yang telah dilakukan.

\section{B. PEMBAHASAN}

a. Perjanjian Dalam Pinjam Meminjam Uang Berbasis Teknologi Finansial Menurut POJK Nomor 77/POJK.01/2016 di PT. Lunaria Annua Teknologi (KoinWorks)

Teknologi finansial berkembang dengan cepat dan mendorong tumbuhnya berbagai layanan keuangan dengan basis teknologi informasi. Kegiatan pinjam meminjam uang secara langsung berdasarkan perjanjian baik tertulis maupun tidak tertulis merupakan praktik yang telah berlangsung di tengah kehidupan masyarakat. Pinjam meminjam secara 


\section{AL-QISTH LAW REVIEW \\ VOL 5 NO. 1 (2021)}

langsung banyak diminati oleh pihak yang membutuhkan dana cepat atau pihak yang karena sesuatu hal tidak dapat diberikan pendanaan oleh industri jasa keuangan konvensional seperti Perbankan, Pasar Modal, atau Perusahaan Pembiayaan.

Segala manfaat ekonomi, kerugian yang ditimbulkan, serta dampak hukum dari kegiatan pinjam meminjam yang dilakukan secara langsung sepenuhnya menjadi tanggung jawab para pihak sesuai dengan kesepakatan yang telah diperjanjikan. Praktik dimaksud dinilai masih terdapat banyak kelemahan yang diantaranya seperti pelaksanaan kegiatan pinjam meminjam dilakukan oleh para pihak yang sudah saling mengenal dan harus bertatap muka, subjektifitas terhadap penilaian risiko gagal bayar, kesulitan dalam penagihan pembayaran, maupun tidak adanya sistemasi pencatatan pelunasan pinjaman yang telah dilakukan.

Perkembangan ekonomi digital, masyarakat terus mengembangkan inovasi penyediaan layanan dalam kegiatan pinjam meminjam yang salah satunya ditandai dengan adanya penyediaan Layanan Pinjam Meminjam Uang Berbasis Teknologi Informasi yang dinilai turut berkontribusi terhadap pembangunan dan perekonomian nasional. Layanan Pinjam Meminjam Uang Berbasis Teknologi Informasi sangat membantu dalam meningkatkan akses masyarakat terhadap produk jasa keuangan secara online baik dengan berbagai pihak tanpa perlu saling mengenal. Keunggulan utama dari Layanan Pinjam Meminjam Uang Berbasis Teknologi Informasi antara lain tersedianya dokumen perjanjian dalam 


\section{2}

\section{AL-QISTH LAW REVIEW \\ VOL 5 NO. 1 (2021)}

bentuk elektronik secara online untuk keperluan para pihak, tersedianya kuasa hukum untuk mempermudah transaksi secara online, penilaian risiko terhadap para pihak secara online, pengiriman informasi tagihan (collection) secara online, penyediaan informasi status pinjaman kepada para pihak secara online, dan penyediaan escrow account dan virtual account di perbankan kepada para pihak, sehingga seluruh pelaksanaan pembayaran dana berlangsung dalam sistem perbankan. Atas hal ini, Layanan Pinjam Meminjam Uang Berbasis Teknologi Informasi dapat memenuhi kebutuhan dana tunai secara cepat, mudah, dan efisien, serta meningkatkan daya saing. Selain itu, Layanan Pinjam Meminjam Uang Berbasis Teknologi Informasi dapat menjadi salah satu solusi untuk membantu pelaku usaha skala mikro, kecil, dan menengah (UMKM) dalam memperoleh akses pendanaan.

Layanan Pinjam Meminjam Uang Berbasis Teknologi Finansial dikenal dengan istilah Financial Technology berbasis Peer to Peer Lending. Sebagaimana dikutip dari laman https:/ / www.koinworks.com Peer to Peer Lending adalah praktek atau metode memberikan pinjaman uang kepada individu atau bisnis dan juga sebaliknya, mengajukan pinjaman kepada Kreditur, yang menghubungkan antara Kreditur dengan Debitur secara online. Selain itu, memungkinkan setiap orang untuk memberikan pinjaman atau mengajukan pinjaman yang satu dengan yang lain untuk berbagai kepentingan tanpa menggunakan jasa dari lembaga keuangan konvensional (bank) sebagai perantara. Pada dasarnya, sistem Peer to Peer Lending ini sangat mirip dengan konsep marketplace online, yang 


\section{AL-QISTH LAW REVIEW \\ VOL 5 NO. 1 (2021)}

menyediakan wadah sebagai tempat pertemuan antara pembeli dengan penjual. Dalam hal Peer to Peer Lending ini, sistem yang ada akan mempertemukan pihak Debitur dengan pihak yang Kreditur. Jadi, boleh dikatakan bahwa Peer to Peer Lending merupakan marketplace untuk kegiatan pinjam meminjam uang.

Penyelenggaraan layanan pinjam meminjam uang secara online ini dilakukan oleh beberapa pihak agar dapat menjalankan mekanisme Teknologi Finansial berbasis Peer to Peer Lending. Para pihak dalam Penyelenggaraan layanan ini antara lain adalah Kreditur, Debitur dan Penyelenggara. Mekanisme Penyelenggaraan Teknologi Finansial berbasis Peer to Peer Lending berbeda dengan perbankan. Peer to Peer Lending tidak menghimpun dana dari masyarakat dalam menyalurkan pembiayaan. Peer to Peer Lending juga berbeda dengan Perusahaan multifinance yang memberikan pembiayaan secara langsung kepada Debitur dengan menggunakan modal perusahaan itu sendiri (balance sheet financing). Peer to Peer Lending adalah aktivitas pembiayaan yang dilakukan secara online dalam sebuah wadah yaitu melalui marketplace. Marketplace tersebut mempertemukan antara Debitur dengan Kreditur. Pendapatan yang diterima oleh Penyelenggara Peer to Peer Lending berasal dari fee dan komisi yang diperoleh dari Kreditur sehingga bukan dari pendapatan bunga. Berikut ini adalah perbedaan alur pinjam meminjam antara Bank Konvensioanl dengan Peer to Peer Lending: 


\section{AL-QISTH LAW REVIEW}

VOL 5 NO. 1 (2021)

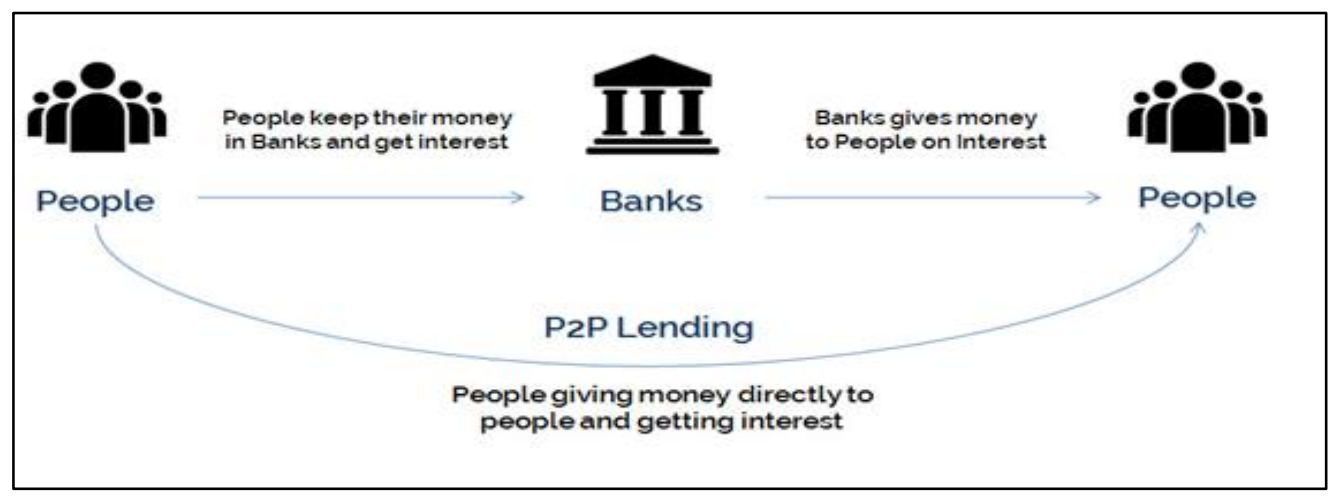

\section{Gambar 1}

Pada alur pinjam meminjam uang pada Bank Konvesional, bank bertindak sebagai intermediasi keuangan antara Deposan (Kreditur) dengan Debitur. Lembaga intermediasi keuangan (financial intermediary) adalah kegiatan pengalihan dana dari pihak yang kelebihan dana (unit ekonomi surplus) kepada pihak yang kekurangan dana (unit ekonomi defisit). Baik pihak kelebihan dana (unit ekonomi surplus) maupun pihak yang kekurangan dana (unit ekonomi defisit) dapat berupa badan usaha, lembaga pemerintah, atau perorangan (Muhammad, Muniarti, 2000).

Pendapatan bank berasal dari selisih antara bunga simpanan dengan bunga pinjaman. Sebagai risk taker mengharuskan bank untuk menahan modal untuk menyerap potensi kerugian. Kemudian deposan memiliki akses informasi yang sangat terbatas atas penggunaan (penyaluran) uangnya. Selanjutnya bank menyediakan buffer likuiditas mengingat ratarata simpanan berjangka waktu lebih pendek dibandingkan dengan kredit. 


\section{5}

\section{AL-QISTH LAW REVIEW \\ VOL 5 NO. 1 (2021)}

Alur pinjam meminjam uang berbasis teknologi finansial melalui Marketplace Lending atau Peer to Peer Lending yaitu Penyelenggara mempertemukan antara Debitur dengan Kreditur melalui platform yang telah disediakan oleh Penyelenggara yang dengan mudah dapat diakses oleh semua orang. Penyelenggara bukan merupakan Kreditur, sehingga tidak mendapatkan pendapatan bunga dan tidak menahan modal untuk menyerap risiko. Pendapatan yang diterima oleh Penyelenggara adalah berasal dari fee dan komisi dari Kreditur. Sebagaimana diakses dari https//:www.buminc.com bahwa, dalam Penyelenggaraan pinjam meminjam uang berbasis teknologi finansial menggunakan sistem skoring kredit seperti perbankan dan mempublikasikan hasilnya pada platform Penyelenggara tersebut. Penyelenggara menyampaikan informasi secara transparan kepada Kreditur sehingga Kreditur mengetahui kepada siapa pembiayaannya diberikan. Mekanisme pinjam meminjam uang berbasis teknologi finansial dilakukan oleh para pihak yang dihubungkan dengan adanya hubungan hukum untuk mengatur kegiatan tersebut. Hubungan hukum para pihak dihubungkan melalui suatu perjanjian atau kontrak. Perjanjian atau kontrak adalah suatu perbuatan dengan mana satu orang atau lebih mengikatkan dirinya terhadap satu orang lain atau lebih saling berjanji untuk melaksanakan suatu hal. (Pasal 1313 Kitab Undang-Undang Hukum Perdata).

Perjanjian pada umumnya dilakukan dengan membuat kesepakatan yang dilakukan secara langsung antara para pihak yang akan saling mengikatkan diri, akan tetapi perjanjian dalam layanan pinjam meminjam 


\section{AL-QISTH LAW REVIEW \\ VOL 5 NO. 1 (2021)}

uang berbasis teknologi finansial dilakukan secara elektronik sehingga perjanjian tersebut berbentuk perjanjian elektronik yang dituangkan dalam dokumen elektronik oleh para pihak. Kontrak elektronik adalah perjanjian para pihak yang dibuat melalui sistem elektronik. (Pasal 1 Angka 17 Undang-Undang Nomor 11 Tahun 2008 Tentang Informasi dan Transaksi Elektronik).

Pembuatan perjanjian elektronik dalam Penyelenggaraan layanan pinjam meminjam uang berbasis teknologi finansial dilakukan tanpa harus bertemu bertatap muka secara langsung. Hal demikian memberikan kemudahan terutama kemudahan akses bagi para pihak yang akan menggunakannya. Perjanjian elektronik yang dibuat dalam layanan pinjam meminjam uang berbasis teknologi finansial memiliki kekuatan hukum yang mengikat bagi para pihak sebagaimana perjanjian pada umumnya. Hal tersebut diatur dalam Pasal 18 Ayat 1 Undang Undang Nomor 11 Tahun 2008 Tentang Informasi dan Transaksi Elektronik yang menyebutkan bahwa "transaksi elektronik yang dituangkan dalam kontrak elektronik mengikat para pihak". Dengan demikian maka perjanjian elektronik tersebut berlaku sebagai suatu undang-undang bagi para pihak yang saling mengikatkan diri, serta mengakibatkan timbulnya sutu hubungan hukum bagi para pihak tersebut. Perjanjian elektronik memiliki kesamaan sebagaimana perjanjian pada umumnya. Perjanjian elektronik karena memiliki kesamaan dengan perjanjian pada umumnya maka untuk bisa dikatakan sah juga harus memenuhi syarat sah perjanjian sebagaimana diatur dalam Pasal 1320 KUHPerdata, yaitu: 


\section{AL-QISTH LAW REVIEW \\ VOL 5 NO. 1 (2021)}

Pertama, kesepakatan mereka yang mengikatkan dirinya. Supaya kontrak atau perjanjian dianggap sah maka para pihak harus sepakat terlebih dahulu terdapat pada segala hal yang ada pada perjanjian. Pada dasarnya kata sepakat adalah pertemuan atau persesuaian kehendak antara para pihak di dalam perjanjian. Persesuaian kehendak saja tidak akan menciptakan atau melahirkan perjanjian. Kehendak terebut harus dinyatakan, sehingga harus ada pernyataan kehendak. Pernyataan kehendak tersebut harus merupakan yang bersangkutan mngehendaki timbulnya hubungan hukum (Satrio, 2001).

Kehendak tersebut harus dimengerti oleh pihak lawan, sehingga kehendak tersebut harus dinyatakan. Pernayataan kehendak dapat dilakukan secara tegas, yaitu pernyataan kehendak diberikan eksplisit dengan cara tertulis, lisan atau dengan tanda. Pernyataan kehendak secara tertulis dapat dilihat dari adanya tanda tangan para pihak. Selain itu, pernyatan kehendak dapat pula dinyatakan secara diam-diam. Hal tersebut tercemin pada sikap dan perbuatan yang dilakukan oleh para pihak (Satrio, 2001).

Kedua, kecakapan untuk membuat suatu perikatan. Cakap merupakan syarat yang umum untuk dapat melakukan perbuatan hukum secara sah yaitu harus sudah dewasa, sehat akal pikiran dan tidak dilarang oleh suatu peraturan perundang-undangan untuk melakukan suatu perbuatan tertentu (Syahrani, 2013). Pada pasal 1329 KUHPerdata menyatakan bahwa setiap orang adalah cakap untuk membuat perjanjian, 


\section{AL-QISTH LAW REVIEW \\ VOL 5 NO. 1 (2021)}

kecuali menurut undang-undang dinyatakan tidak cakap. Pasal 1330 KUHPerdata tidak menentukan siapa yang cakap melakukan perbuatan untuk mengadakan suatu perjanjian, tetapi menentukan secara negatif siapa yang tidak cakap untuk mengadakan perjanjian. Orang yang tidak cakap tersebut adalah orang yang belum dewasa, mereka yang dibawah pengampuan dan semua orang yang dilarang undang-undang untuk membuat suatu perjanjian (Khairandi, 2014).

Berdasarkan Buku I Pasal 330 KUHPerdata, seorang dianggap dewasa jika dia telah berusia 21 (dua puluh satu) tahun atau telah menikah. Kemudian pengaturan mengenai batas kedewasaan juga ditemukan dalam Undang-Undang Nomor 1 Tahun 1974 tentang Perkawinan bahwa kedewasaan seseorang ditentukan bahwa anak berada dibawah kekuasaan orang tua atau wali sampai berusia 18 (delapan belas) tahun. Khusus perjanjian dengan perjanjian yang dibuat dihadapan notaris diatur pula pada Undang-Undang Nomor 30 Tahun 2004 tentang Jabatan Notaris yang menentukan batas kedewasaan tersebut adalah 18 (delapan belas) tahun atau belum menikah dan cakap melakukan perbuatan hukum. Dengan demikian, kecapakapan untuk melakukan suatu perjanjian yang dibuat tidak hanya dikaitkan dengan batas umur kedewasaan, tetapi juga dikaitkan dengan tolak ukur yang lain, misalnya tidak berada di bawah pengampuan. Tidak hanya dewasa tetapi juga cakap melakukan suatu perbuatan hukum (Khairandi, 2014). 


\section{AL-QISTH LAW REVIEW \\ VOL 5 NO. 1 (2021)}

Ketiga, suatu hal tertentu. Suatu hal tertentu dalam perjanjian adalah barang yang dijadikan objek suatu perjanjian. Menurut Pasal 1333 KUHPerdata barang yang menjadi objek suatu perjanjian harus tertentu, setidak-tidaknya harus ditentukan jenisnya, sedangkan jumlahnya tidak perlu ditentukan asalkan saja dapat ditentukan atau diperhitungkan. Selanjutnya dalam Pasal 1334 ayat (1) KUHPerdata ditentukan bahwa barang-barang yang baru akan ada kemudian hari juga dapat menjadi objek suatu perjanjian. Pasal 1334 ayat (2) KUHPerdata bahwa barang yang akan masuk hak warisan seseoarang karena yang lain akan meninggal dunia dilarang dijadikan objek suatu perjanjian meskipun dengan kesepakatan orang yang akan meninggal dunia dan akan meninggalkan barang-barang warisan tersebut. Kemudian dalam Pasal 1332 KUHPerdata ditentukan bahwa barang-barang yang dapat dijadikan objek perjanjian hanyalah barang yang dapat diperdagangkan (Syahrani, 2013).

Keempat, suatu sebab yang halal. Suatu kontrak atau perjanjian disamping harus ada kausanya, akan tetapi kausa tersebut juga harus halal. Kausa suatu perikatan adalah sebagai alasan penggerak yang menjadi dasar kesediaan Debitur untuk menerima keterikatan untuk memenuhi isi (prestasi) perikatan. Menerima perikatan berarti menerima keterikatan kewajiban-kewajiban yang timbul dari perikatan tersebut. Dengan kata lain, menerima keterikatan untuk memberikan prestasi perikatan. Seorang yang terikat untuk melaksanakan isi perjanjian tidak hanya didasarkan pada kata sepakat saja, tetapi juga harus didasarkan adanya kausa (Khairandi, 2014). 


\section{AL-QISTH LAW REVIEW \\ VOL 5 NO. 1 (2021)}

Kausa halal dimaksud adalah kausa hukum yang ada tidak bertentangan dengan peraturan perundang-undangan atau ketertiban umum, atau kesusilaan. Jika objek dalam perjanjian ilegal atau bertentangan dengan kesusilaan atau ketertiban umum maka perjanjian tersebut menjadi batal demi hukum. Pasal 1335 Jo 1337 KUHPerdata menyatakan bahwa suatu kausa dinyatakan terlarang jika bertentangan dengan undang-undang, kesusilaan, dan ketertiban umum. Suatu kausa dinyatakan bertentangan dengan undang-undang jika kausa dalam perjanjian yang bersangkutan isinya bertentangan dengan undang-undang yang berlaku (Khairandi, 2014).

\section{b. Perjanjian Dalam Pinjam Meminjam Uang Berbasis Teknologi Finansial Menurut POJK Nomor 77/POJK.01/2016 di PT. Lunaria Annua Teknologi (KoinWorks) Antara Kreditur dengan Penyelenggara}

Pada pelaksanaan layanan pinjam meminjam uang berbasis teknologi finansial, perjanjian elektronik tersebut menimbulkan hubungan hukum. Hubungan hukum tersebut lahir dari hubungan kontraktual para pihak, baik bagi kreditur, debitur maupun Penyelenggara layanan Pinjam Meminjam Uang Berbasis Teknologi Finansial. Hubungan hukum tersebut telah diatur sebagaimana Pasal 18 Peraturan Otoritas Jasa Keuangan Nomor 77/POJK.01/2016 yang mengatur adanya perjanjian bagi para pihak. Peraturan tersebut pertama mengatur mengenai perjanjian antara 


\section{AL-QISTH LAW REVIEW \\ VOL 5 NO. 1 (2021)}

Penyelenggara dengan Kreditur. Kedua, mengatur mengenai perjanjian antara kreditur dengan debitur.

Dalam mekanisme layanan pinjam meminjam uang berbasis teknologi finansial, sebagaimana dikutip dari https//:www.koinworks.com bahwa Kreditur yang akan memberikan pinjaman dana kepada Debitur harus menyetujui syarat dan ketentuan khusus yang telah diatur oleh Penyelenggara selaku platform layanan pinjam meminjam uang berbasis teknologi finansial. Adapun syarat dan ketentuan khusus tersebut adalah mengenai Kreditur selaku pihak yang akan mengajukan pemberian dana melalui platform harus setuju dan sepakat untuk menunjuk Penyelenggara layanan pinjam meminjam uang berbasis teknologi finansial untuk bertindak untuk dan atas nama Kreditur yaitu untuk menyalurkan dananya kepada pihak Debitur.

Berdasarkan mekanisme tersebut di atas, terdapat hubungan hukum antara Kreditur dengan Penyelenggara layanan pinjam meminjam uang berbasis teknologi finansial. Perjanjian antara Penyelenggara dengan Kreditur adalah perjanjian pemberian kuasa yaitu kuasa khusus. Perjanjian pemberian kuasa sebagaimana Pasal 1792 KUHPerdata adalah suatu perjanjian dengan mana seorang memberikan kekuasaan kepada seorang lain, yang menerimanya, untuk atas namanya menyelenggarakan suatu urusan. Menyelenggarakan suatu urusan dimaksud adalah melakukan suatu perbuatan hukum yang mempunyai suatu akibat hukum (Subekti, 2014). Pihak yang telah diberi kuasa dapat dikatakan sebagai kuasa untuk 


\section{AL-QISTH LAW REVIEW \\ VOL 5 NO. 1 (2021)}

melakukan suatu perbuatan hukum atas nama orang yang telah memberikan kuasa atau dapat dikatakan bahwa ia merupakan perwakilan dari dari si pemberi kuasa. Maka dengan demikian segala perbuatan yang dilakukan penerima kuasa adalah tanggung jawab dari pemberi kuasa sehingga segala hak dan kewajiban yang timbul dari perbuatan yang dilakukannya menjadi hak dan kewajiban pihak yang memberi kuasa (Subekti, 2014).

Pemberian kuasa dapat dilakukan secara khusus hal ini diatur pada Pasal 1795 KUHPerdata, yaitu hanya mengenai satu kepentingan tertentu atau lebih, atau secara umum yang meliputi segala kepentingan pemberi kuasa. Surat kuasa khusus, dijelaskan mengenai tindakan-tindakan apa saja yang dapat dilakukan oleh penerima kuasa dan adanya tindakantindakan yang dirinci dalam surat kuasa tersebut, maka surat kuasa tersebut menjadi surat kuasa khusus (Kusumasari, 2011). Perbuatan Penyelenggara layanan pinjam meminjam uang berbasis teknologi finansial telah ditentukan di dalam ketentuan khusus tersebut yaitu untuk menyalurkan dana Kreditur kepada pihak Debitur. Maka dengan demikian perbuatan yang dapat dilakukan oleh Penyelenggara selaku penerima kuasa adalah terbatas, yaitu sebatas kuasa khusus yang diberikan kepadanya untuk menyalurkan dana Kreditur kepada Debitur.

Suatu kuasa dapat diberikan dan diterima dalam bentuk akta resmi atau dengan suatu surat di bawah tangan ataupun dengan kuasa lisan (Pasal 1793 Kitab Undang-Undang Hukum Perdata). Akta resmi yang 


\section{AL-QISTH LAW REVIEW \\ VOL 5 NO. 1 (2021)}

dimaksud seperti akta notaris, akta yang dilegalisir di kepaniteraan pengadilan, akta yang dibuat oleh pejabat pamong dan sebagaimanya. Penerimaan suatu kuasa dapat pula terjadi secara diam-diam, ini berbarti terjadi dengan sendirinya. Kuasa diam-diam dapat disimpulkan dari pelaksanaan kuasa itu oleh yang diberi kuasa berdasarkan tindakan yang dilakukannya (Harahap, 1982).

Pada umumnya pemberian kuasa terjadi karena adanya persetujuan antara pemberi kuasa dengan penerima kuasa. Sifat persetujuan kuasa adalah konsensual. Artinya perjanjian pemberian kuasa lahir apabila ada kata sepakat atau ada persesuaian kehendak diantara para pihak yang membuat perjanjian tersebut. Persesuaian kehendak saja tidak akan menciptakan atau melahirkan perjanjian karena kehendak tersebut itu sendiri dapat diungkapkan dengan berbagai cara. Dapat secara tegas maupun secara diam-diam. Pernyataan kehendak dapat pula dilakukan secara tertulis, lisan, maupun dengan tanda (Khairandi, 2014).

Perjanjian pemberian kuasa pada mekanisme layanan pinjam meminjam uang berbasis teknologi finansial dilakukan tidak secara diamdiam akan tetapi perjanjian tersebut dibuat melalui media elektronik yang terdapat pada platform Penyelenggara layanan pinjam meminjam uang berbasis teknologi finansial. Pada saat Kreditur akan mengajukan pendanaan pada platform Penyelenggara, Kreditur harus menyetujui mengenai ketentuan yang telah ditentukan pada platform tersebut. Kreditur 


\section{AL-QISTH LAW REVIEW \\ VOL 5 NO. 1 (2021)}

harus setuju dan sepakat untuk memberikan kuasa pada platform Penyelenggara untuk menyalurkan dana Kreditur kepada Debitur.

Bentuk kesepakatan yang terjadi antara Kreditur selaku pemberi kuasa dengan Penyelenggara selaku penerima kuasa adalah pada saat Kreditur sepakat atau menyetujui terhadap syarat maupun ketentuan yang diberikan oleh platform Penyelenggara yang diikuti dengan pernyataan kehendak. Pernyataan kehendak tersebut dilakukan dengan cara menekan tombol persetujuan berupa mengklik centang pada platform. Persetujuan tersebut adalah memberikan kuasa pada Penyelenggara selaku platform layanan pinjam meminjam uang berbasis teknologi finansial untuk dapat menyalurkan dana Kreditur kepada Debitur. Kemudian dapat melanjutkan pendaftaran sebagai Kreditur pada platform Penyelenggara layanan pinjam meminjam uang berbasis teknologi finansial.

\section{c. Perjanjian Dalam Pinjam Meminjam Uang Berbasis Teknologi Finansial Menurut POJK Nomor 77/POJK.01/2016 di PT. Lunaria Annua Teknologi (KoinWorks) Antara Kreditur dengan Debitur}

Selain perjanjian antara Kreditur dengan Penyelenggara layanan pinjam meminjam uang berbasis teknologi finansial terdapat pula perjanjian lainnya. Perjanjian lain tersebut adalah perjanjian antara Kreditur dengan Debitur. Perjanjian yang terjadi antar antara Kreditur dengan Debitur merupakan perjanjian pinjam meminjam (utang piutang) pada umumnya sebagaimana telah diatur dalam Pasal 1754 KUHPerdata. Perjanjian tersebut dibuat karena adanya persesuaian kehendak oleh para 


\section{5}

\section{AL-QISTH LAW REVIEW \\ VOL 5 NO. 1 (2021)}

pihak yaitu untuk melakukan pendanaan dan melakukan peminjaman dana kepada pihak lainnya. Para pihak kemudian bersepakat untuk saling mengikatkan diri untuk melakukan suatu hubungan hukum.

Perjanjian tersebut dilakukan dengan bantuan media internet untuk dapat menggunakan platform layanan pinjam meminjam uang berbasis teknologi finansial. Bentuk perjanjian pinjam meminjam tersebut adalah perjanjian elektronik yang memiliki kekuatan hukum yang sama sebagaimana perjanjian pada umumnya. Oleh sebab itu perjanjian elektronik berlaku sebagai undang-undang bagi mereka yang membuatnya (Pasal 18 Ayat (1) Undang-Undang Nomor 11 Tahun 2008 Tentang Informasi dan Transaksi Elektronik). Perjanjian tersebut atas dasar kebebasan berkontrak yang mana para pihak bebas membuat perjanjian yang mereka inginkan. Perjanjian atau kontrak yang telah dibuat haruslah dipatuhi oleh para pihak sebagai bentuk itikad baik pelaksanaan kontrak oleh pihak yang membuat perjanjian itu sendiri. Perjanjian tersebut kemudian melahirkan suatu hubungan hukum sehingga timbul hak dan kewajiban bagi para pihak untuk melaksanakannya.

Perjanjian elektronik tersebut dituang dalam dokumen elektronik. Dokumen Elektronik adalah setiap informasi elektronik yang dibuat, diteruskan, dikirimkan, diterima, atau disimpan dalam bentuk analog, digital, elektromagnetik, optikal, atau sejenisnya, yang dapat dilihat, ditampilkan, dan/atau didengar melalui komputer atau Sistem Elektronik termasuk tetapi tidak terbatas pada tulisan, suara, gambar, peta rancangan, 


\section{AL-QISTH LAW REVIEW \\ VOL 5 NO. 1 (2021)}

foto atau sejenisnya, huruf, tanda, angka, kode akses, simbol atau perforasi yang memiliki makna atau arti atau dapat dipahami oleh orang yang mampu memahaminya sebagaimana dimaksud dalam Undang-Undang Nomor 11 Tahun 2008 tentang Informasi dan Transaksi Elektronik (Pasal 1 Angka 12 Peraturan Otoritas Jasa Keuangan Nomor 77/POJK.01/2016 Tentang Layanan Pinjam Meminjam Uang Berbasis Teknologi Informasi). Dokumen elektronik tersebut harus dipenuhi oleh para pihak baik Kreditur maupaun Debitur. Dokumen elektronik tersebut wajib paling sedikit memuat: a. Nomor perjanjian; b. Tanggal perjanjian; c. Identitas para pihak; d. Ketentuan mengenai hak dan kewajiban para pihak; e. Jumlah pinjaman; f. Suku Bunga pinjaman; g. Nilai Angsuran; h. Jangka waktu; i. Objek Jaminan (jika ada); j. Rincian Biaya Terkait; k. Ketentuan Mengenai Denda (jika ada); dan 1. Mekanisme Penyelesaian Sengketa. (Pasal 20 Ayat (2) Peraturan Otoritas Jasa Keuangan Nomor 77/POJK.01/2016 Tentang Layanan Pinjam Meminjam Uang Berbasis Teknologi Informasi).

Pada mekanisme pembuatan perjanjian antara Kreditur dengan Debitur para pihak tidak perlu saling bertemu dan saling berhadapan (face to face). Segala bentuk aktivitas dihubungkan dengan bantuan Penyelenggara layanan pinjam meminjam uang berbasis teknologi finansial. Penyelenggara dalam hal ini adalah sebagai perantara para pihak melalui platform Penyelenggara. Perjanjian elektronik tersebut melahirkan suatu hubungan hukum bagi pihak Kreditur dengan Debitur. Para pihak tersebut dihubungkan melalui hubungan kontraktual yang dibuat oleh para pihak. Para pihak harus mentaati apa yang telah mereka perjanjikan 


\section{AL-QISTH LAW REVIEW \\ VOL 5 NO. 1 (2021)}

sebagai undang-undang yang mengikat bagi para pihak yang membuatnya. Dari hubungan kontraktual tersebut timbul hak dan kewajiban yang harus dipenuhi. Secara garis besar Kreditur wajib memberikan dana sebesar yang diperjanjikan pada waktu yang telah ditentukan. Dari kewajiban tersebut timbul hak yaitu pengembalian dana beserta bunga yang diperjanjikan dengan Debitur. Bagi Debitur berhak mendapatkan pinjaman dana sesuai kesepakatan yang dilakukan. Dari hak tersebut timbul kewajiban yang harus dilakukan yaitu untuk membayar dana yang dipinjamkan beserta bunga yang diperjanjikan.

\section{d. Perlindungan Hukum Bagi Kreditur Dalam Pinjam Meminjam Uang Berbasis Teknologi Finansial Menurut POJK Nomor 77/POJK.01/2016 di PT. Lunaria Annua Teknologi (KoinWorks)}

Pada penyelenggara KoinWorks hanya menyediakan marketplace (tempat) bagi Kreditur dan Debitur untuk melakukan pinjam meminjam uang berbasisi teknologi finansial pada platform Penyelenggara. Penyelenggara bukan sebagai pihak dalam perjanjian pinjam meminjam yang dilakukan oleh Kreditur dan Debitur melainkan hanya sebagai pihak yang diberi kuasa oleh Kreditur untuk menyalurkan dananya kepada Debitur. Berdasarkan hal tersebut, Penyelenggara tidak memiliki tanggung jawab atau kewajiban dalam perjanjian pinjam meminjam uang berbasis teknologi finansial tersebut, karena pada dasarnya perjanjian pinjam meminjam tersebut hanya dilakukan oleh Kreditur dan Debitur. Ketiadaan 


\section{AL-QISTH LAW REVIEW \\ VOL 5 NO. 1 (2021)}

hubungan hukum dalam perjanjian pinjam meminjam uang berbasis teknologi finansial antara Penyelenggara dengan pengguna layanan pinjam meminjam tersebut menimbulkan konsekuensi hukum. Khususnya bagi Kreditur tidak dapat mengajukan tuntutan hukum kepada Penyelenggara apabila Kreditur mengalami kerugian sebagai akibat tindakan Penyelenggara dalam Penyelenggaraan layanan pinjam meminjam uang berbasis teknologi finansial. Kerugian yang dimaksud adalah apabila terjadi gagal bayar oleh Debitur akibat tindakan Penyelenggara yaitu menyeleksi, menganalisis, dan menyetujui aplikasi pinjaman yang dianggap berkualitas serta layak untuk ditawarkan kepada Kreditur.

Apabila terjadi gagal bayar oleh Debitur, Penyelenggara hanya dapat mengusahakan melalui unit penagihan, membantu melakukan mediasi dan mengusahakan agar tidak terjadi kredit macet akan tetapi tidak menjamin keberhasilannya. Hal tersebut jelas tidak memberikan perlindungan hukum khususnya bagi Kreditur. Gagal bayar tersebut bisa terjadi akibat ketidaktepatan Penyelenggara dalam menyeleksi, menganalisis, dan menyetujui aplikasi pinjaman yang diajukan oleh Debitur untuk ditawarkan kepada Kreditur. Berdasarkan hal tersebut jelas bahwa Penyelenggara tidak memberikan penawaran Debitur yang berkualitas, sehingga hal tersebut dapat menyebabkan gagal bayar dan pihak yang dirugikan tentulah Kreditur. 


\section{AL-QISTH LAW REVIEW \\ VOL 5 NO. 1 (2021)}

Akibat tindakan Penyelenggara menyeleksi, menganalisis, dan menyetujui aplikasi pinjaman yang diajukan oleh Debitur untuk ditawarkan kepada Kreditur, Penyelenggara seharusnya dapat bertanggung jawab atas tindakannya kepada Kreditur karena tidak memberikan penawaran Debitur yang berkulitas padahal sudah jelas bahwa Kreditur hanya dapat memberikan dana kepada Debitur yang diajukan oleh Penyelenggara. Pada praktiknya terdapat keterbatasan tanggung jawab oleh KoinWorks selaku Penyelenggara layanan pinjam meminjam uang berbasis teknologi finansial jika terjadinya gagal bayar oleh Debitur jelas bertentangan dengan Pasal 37 POJK Nomor 77/POJK.01/2016 tentang Layanan Pinjam Meminjam Uang berbasis Teknologi Informasi yang menyatakan bahwa: "Penyelenggara wajib bertanggung jawab atas kerugian pengguna yang timbul akibat kesalahan dan/atau kelalaian, direksi, dan/atau pegawai Penyelenggara."

Bahwa dalam hal ini Penyelenggara wajib bertanggung jawab akibat kesalahan atau kelalainnya yaitu mengajukan penawaran Debitur yang tidak berkulitas yang kemudian menyebabkan terjadi gagal bayar sehingga Kreditur dirugikan akibat tindakan Penyelenggara. Bentuk pertanggungjawaban tersebut adalah atas kegiatan Penyelenggara karena tidak dapat mengelola dan mengoperasikan layanan pinjam meminjam uang berbasis teknologi finansial dari pihak Kreditur kepada pihak Debitur dengan baik hingga menimbulkan kerugian pada salah satu pihak (Pasal 5 Ayat (1) Peraturan Otoritas Jasa Keuangan Nomor 77/POJK.01/2016 tentang Layanan Pinjam Meminjam Uang Berbasis Teknologi Informasi). 


\section{AL-QISTH LAW REVIEW \\ VOL 5 NO. 1 (2021)}

Belum adanya perlindungan hukum bagi Kreditur pada praktik layanan pinjam meminjam uang berbasis teknologi finansial ini menimbulkan tidak adanya kepastian hukum bagi penggunanya khususnya Kreditur.

Bentuk perlindungan hukum bagi pengguna layanan Teknologi Finansial berbasis Peer to Peer Lending baik Kreditur maupun Debitur dapat dibedakan menjadi dua macam, yaitu perlindungan secara preventif dan perlindungan hukum secara represif. Perlindungan hukum secara preventif adalah perlindungan hukum yang bertujuan untuk mencegah terjadinya sengketa dan dilakukan sebelum terjadinya sengketa. Dengan demikian, nampak bahwa POJK No.77/POJK.01/2016 tentang layanan pinjam meminjam berbasis teknologi informasi belum sepenuhnya memberikan perlindungan hukum khususnya bagi Kreditur, padahal Indonesia telah mendeklarasikan sebagai negara hukum (Pasal 1 ayat (3) Undang-Undang Dasar Negara Republik Indonesia Tahun 1945). Negara hukum adalah negara yang berdiri di atas hukum yang menjamin keadilan kepada warga negaranya.

Sehubungan dengan pendeklarasian bahwa Indonesia adalah negara hukum, maka setiap perbuatan harus diatur berdasarkan peraturan hukum. Peraturan hukum yang sebenarnya hanya ada jika peraturan hukum itu mencerminkan keadilan bagi pergaulan hidup antar warga negaranya (Khairandi, 2014). Hukum itu penting karena hukum yang berlaku akan mengikat pihak-pihak terkait. Pentingnya perlindungan 


\section{AL-QISTH LAW REVIEW \\ VOL 5 NO. 1 (2021)}

hukum khususnya bagi Kreditur dalam keberlangsungan dunia bisnis dan investasi adalah sebagai bentuk kepastian hukum bagi penggunanya.

Selain dari pada itu perlindungan hukum bagi Pengguna Layanan Teknologi Finansial berbasis Peer to Peer Lending sebelum terjadinya sengketa juga dapat dilakukan dengan upaya-upaya dari Penyelenggara. Upaya Penyelenggara dalam melindungi para Penggunanya sebelum terjadinya sengketa salah satunya ialah dengan cara menerapkan prinsipprinsip dasar perlindungan hukum bagi Pengguna layanan Teknologi Finansial. Prinsip-prinsip tersebut diatur pada Pasal 29 POJK Nomor 77/POJK.01/2016 Tentang Layanan Pinjam Meminjam Uang Berbasis Teknologi Informasi antara lain prinsip transparansi, perlakuan yang adil, keandalan, kerahasiaan dan keamanan data, dan penyelesaian sengketa Pengguna secara sederhana, cepat dan biaya terjangkau.

Perlindungan hukum secara represif adalah perlindungan hukum yang tujuannya untuk menyelesaikan sengketa. Perlindungan hukum ini baru bisa dilakukan setelah timbulnya sengketa terlebih dahulu. Sengketa dalam Penyelenggaraan Teknologi Finansial berbasis Peer to Peer Lending bisa terjadi antara Pengguna dengan Pengguna lainnya maupun dengan antara Pengguna dengan Penyelenggara. Jika sengketa tersebut benar terjadi maka ada mekanisme tertentu untuk dapat menyelesaikan masalah tersebut. Pihak yang merasa dirugikan dapat mengajukan pengaduan agar sengketa yang terjadi dapat segera terselesaikan. Adanya tindakan pengaduan dari Pengguna layanan Teknologi Finansial berbasis Peer to Peer 


\section{AL-QISTH LAW REVIEW \\ VOL 5 NO. 1 (2021)}

Lending kepada Penyelenggara platform, hal tersebut membuat Penyelenggara harus segera menindak lanjutinya. Setelah menerima pengaduan dari pihak yang dirugikan dalam hal ini Pengguna, sebagaimana Pasal 38 POJK Nomor 1/POJK.07/2013 tentang Perlindungan Konsumen Sektor Jasa Keuangan bahwa pelaku jasa keuangan dalam hal ini adalah Penyelenggara layanan Teknologi Finansial berbasis Peer to Peer Lending wajib melakukan:

a. Pemeriksaan internal atas pengaduan secara kompeten, benar, dan obyektif;

b. Melakukan analisis untuk memastikan kebenaran pengaduan;

c. Menyampaiakan pernyataan maaf dan menawarkan ganti rugi (redress/remedy) atau perbaikan produk dan/atau layanan, jika pengaduan konsumen benar.

Berdasarkan ketentuan POJK tersebut, apabila dikemudian hari terjadi tindakan gagal bayar oleh Debitur dan gagal bayar tersebut terbukti akibat kesalahan atau kelalain dari Penyelenggara, maka Penyelenggara wajib memberikan ganti rugi atas perbuatannya tersebut. Kreditur selaku pihak yang dirugikan berhak menerima ganti rugi dari Pihak Penyelenggara. Namun, apabila dalam hal pengaduan tidak mencapai suatu kesepakatan, maka Kreditur dapat melakukan penyelesaian sengketa tersebut di luar maupun di dalam pengadilan. Sebagaimana Pasal 39 Ayat (1) POJK Nomor 1/POJK.07/2013 Tahun 2013 tentang Perlindungan Konsumen Sektor Jasa Keuangan bahwa penyelesaian sengketa di luar 


\section{AL-QISTH LAW REVIEW \\ VOL 5 NO. 1 (2021)}

pengadilan dapat dilakukan melalui lembaga alternative penyelesaian sengketa atau dapat menyampaikan permohonannya kepada Otoritas Jasa Keuangan untuk memfasilitasi penyelesian pengaduan konsumen (pengguna layanan Teknologi Finansial berbasis Peer to Peer Lending) yang dirugikan oleh pelaku jasa keuangan yaitu Penyelenggara.

Kegiatan operasional Penyelenggara dalam menyediakan, mengelola, dan mengoperasikan layanan pinjam meminjam uang berbasis teknologi finansial dilakukan oleh pegawai Penyelenggara. Pegawai Penyelenggara jugalah yang menyeleksi, menganalisis, dan menyetujui aplikasi pinjaman yang dianggap berkualitas serta layak untuk ditawarkan kepada Kreditur. Sehingga para pegawai dalam hal ini bertindak atas nama Penyelenggara. Terjadinya gagal bayar adalah sebagai bentuk kesalahan atau kelalaian dari pegawai Penyelenggara dalam mengelola dan mengoperasikan layanan pinjam meminjam uang berbasis teknologi finansial sehingga timbul kerugian bagi Kreditur. Penyelenggara tetap wajib bertanggung jawab atas tindakan pegawainya tersebut. Penyelenggara sebagai pelaku layanan pinjam meminjam uang berbasis teknologi finansial dapat dikenai sanksi dalam Pasal 47 POJK Nomor 77/POJK.01/2016 tentang Layanan Pinjam Meminjam Uang Berbasis Teknologi Informasi. Sanksi yang dapat diberikan kepada Penyelenggara yang telah melanggar ketentuan Peraturan Otoritas Jasa Keuangan ini dikenakan sanksi adminitrasi yakni; Peringatan tertulis; Denda yaitu kewajiban untuk membayar sejumlah uang tertentu; Pembatasan kegiatan usaha; danPencabutan izin. 


\section{AL-QISTH LAW REVIEW \\ VOL 5 NO. 1 (2021)}

Otoritas Jasa Keuangan sebagaimana dimaksud dalam Pasal 5 Undang-Undang Nomor 21 Tahun 2011 tentang Otoritas Jasa Keuangan menyatakan bahwa OJK berfungsi menyelenggarakan sistem pengaturan dan pengawasan yang berintegrasi terhadap keseluruhan kegiatan di dalam sektor jasa keuangan. Tugas OJK adalah melaksanakan tugas pengaturan dan pengawasan terhadap kegiatan jasa keuangan di sektor Perasuransian, Dana Pensiun, Lembaga Pembiayaan, dan Lembaga Jasa Keuangan Lainnya (Pasal 6 huruf c Undang-Undang Nomor 21 Tahun 2011 tentang Otoritas Jasa Keuangan). Berdasarkan peraturan tersebut, juga memberikan perlindungan hukum bagi Kreditur di mana layanan Teknologi Finansial berbasis Lending merupakan bentuk sumber pendanaan terbaru yang temasuk dalam kategori lembaga jasa keuangan lainnya.

Konsep dari layanan Teknologi Finansial berbasis Peer to Peer Lending menyalurkan dana dari Kreditur kepada Debitur dalam suatu platform yang disedikan oleh Penyelenggara untuk menciptakan suatu peminjaman yang memadai yang dibutuhkan oleh penggunanya. Kegiatan pinjam meminjam uang berbasis Teknologi Finansial merupakan wewenang dari OJK untuk mengatur dan mengawasi terhadap seluruh kegiatan dalam sektor jasa keuangan. Sehingga dengan demikian OJK harus siap dengan mekanisme penyelesaian masalah yang akan timbul dikemudian hari apabila terjadi gagal bayar oleh Debitur sehingga menyebabkan kerugian bagi Kreditur dalam mekanisme layanan Teknologi Finansial berbasis Peer to Peer Lending. 


\section{5 \\ AL-QISTH LAW REVIEW \\ VOL 5 NO. 1 (2021)}

\section{PENUTUP}

Berdasarkan pembahasan yang dilakukan pada bagian sebelumnya, maka penelitian ini menarik kesimpulan sebagai berikut:

a. Pada mekanisme penyelenggaraan layanan pinjam meminjam uang berbasis teknologi finansial di PT. Lunaria Annua Teknologi (KoinWorks), hubungan hukum yang terjadi ialah antara Kreditur dengan Penyelenggara layanan pinjam meminjam uang berbasis teknologi finansial dan antara Kreditur dengan Debitur. Hubungan hukum antara Kreditur dengan Penyelenggara adalah perjanjian pemberian kuasa sebagaimana Pasal 1792 Kitab Undang-Undang Hukum Perdata. Penyelenggara layanan pinjam meminjam uang berbasis teknologi finansial diberi kuasa oleh Kreditur bertindak untuk dan atas nama Kreditur dalam menyalurkan dana Kreditur kepada Debitur. Dari kuasa tersebut Peyelenggara dapat mengelola dana Kreditur kemudian disalurkan dalam bentuk pinjaman kepada Debitur yang dianggap cukup berkualitas dari hasil analisis dan seleksi Penyelenggara. Sedangkan hubungan hukum antara Kreditur dengan Debitur dalam penyelenggaraan layanan pinjam meminjam uang berbasis teknologi finansial adalah perjanjian pinjam meminjam (utang piutang) sebagaimana diatur dalam Pasal 1754 Kitab Undang-Undang Hukum Perdata. Berdasarkan hubungan hukum tersebut, perjanjian pinjam meminjam uang berbasis teknologi finansial hanya terjadi 


\section{AL-QISTH LAW REVIEW \\ VOL 5 NO. 1 (2021)}

antara Kreditur dengan Debitur. Penyelenggara layanan pinjam meminjam uang berbasis teknologi finansial dalam hal ini KoinWorks bukanlah sebagai pihak pada hubungan hukum tersebut. Apabila terjadi gagal bayar oleh Debitur, Kreditur tidak dapat meminta pertanggungjawaban dari pihak Penyelenggara karena pada dasarnya Penyelenggara bukan sebagai pihak dalam perjanjian pinjam meminjam tersebut. Faktanya, Kreditur hanya dapat menyalurkan dananya kepada Debitur yang dianggap berkualitas dan layak untuk diberi pinjaman berdasarkan hasil analisis dan seleksi dari Penyelenggara. Berdasarkan hal tersebut jelas Kreditur sangat rentan dirugikan apabila terjadi gagal bayar dari Debitur. Oleh sebab itu jelas belum ada perlindungan hukum bagi Kreditur apabila terjadi gagal bayar pada mekanisme penyelenggaraan layanan pinjam meminjam uang berbasis teknologi finansial di PT. Lunaria Annua Teknologi (KoinWorks). Perlindungan hukum sangat diperlukan untuk menjamin kepastian hukum khususnya bagi Kreditur apabila terjadi gagal bayar dari pihak Debitur. Untuk memberikan perlindungan hukum bagi Kreditur dapat dilakukan secara preventif dan represif. Perlindungan hukum secara preventif dilakukan dengan upaya menerapkan prinsip dasar dari Penyelenggara sebelum terjadinya sengketa. Prinsip dasar tersebut diatur pada Pasal 29 POJK Nomor 77/POJK.01/2016 yaitu prinsip transparansi, perlakuan yang adil, keandalan, kerahasiaan dan keamanan data, dan penyelesaian sengketa Pengguna secara sederhana, cepat dan biaya terjangkau. Perlindungan hukum secara represif 


\section{AL-QISTH LAW REVIEW \\ VOL 5 NO. 1 (2021)}

dilakukan setelah terjadinya sengketa. Pihak yang dirugikan segera membuat tindakan pengaduan. Jika terbukti benar kerugian yang dialami Kreditur karena kesalahan atau kelalaian Penyelenggara dalam menganalisis dan menyeleksi calon Debitur, maka berdasarkan Pasal 37 POJK Nomor 77/POJK.01/2016 tentang Layanan Pinjam Meminjam Uang berbasis Teknologi Informasi dan Pasal 38 POJK Nomor 1/POJK.07/2013 tentang Perlindungan Konsumen Sektor Jasa Keuangan, Penyelenggara wajib memberikan ganti rugi kepada pihak yang dirugikan akibat kesalahan atau kelalaian Penyelenggara. Selain itu, sebagaimana Pasal 5 Undang-Undang Nomor 21 Tahun 2011 tentang Otoritas Jasa Keuangan, OJK bertugas untuk mengatur dan mengawasi terhadap seluruh kegiatan dalam sektor jasa keuangan. Kegiatan pinjam meminjam uang berbasis teknologi finansial adalah salah satu wewenang dari OJK, oleh sebab itu OJK berkewajiban untuk mengatur dan mengawasi terhadap seluruh kegiatan pada penyelenggaraan layanan pinjam meminjam uang berbasis teknologi finansial tersebut.

b. Mekanisme layanan pinjam meminjam uang berbasis teknologi finansial yang diselenggarakan oleh PT. Lunaria Annua Teknologi (KoinWorks) telah berpedoman pada POJK Nomor 77/POJK.01/2016 tentang Layanan Pinjam Meminjam Uang berbasis Teknologi Informasi, sehingga seluruh proses dan prosedur yang dilaksanakan oleh para pihak baik Penyelenggara, Kreditur maupun Debitur dalam penyelenggaraan layanan pinjam meminjam uang berbasis teknologi 


\section{AL-QISTH LAW REVIEW \\ VOL 5 NO. 1 (2021)}

finansial telah sesuai dengan ketentuan yang diatur dalam POJK Nomor 77/POJK.01/2016 tentang Layanan Pinjam Meminjam Uang berbasis Teknologi Informasi.

\section{DAFTAR PUSTAKA}

Djumhana, M. (201). Hukum Perbankan di Indonesia. (Bandung: Citra Aditya Bakti.

Harahap. M. Y. (1982). Segi-Segi Hukum Perjanjian. Bandung: Alumni.

Imaniyati, N. S. (2010) Pengantar Hukum Perbankan di Indonesia. Bandung: Refika Aditama.

Khairandy, R. (2014). Hukum Kontrak Indonesia Dalam Perspektif Perbandingan (Bagian Pertama). Yogyakarta: UII Press.

Muhammad. A., Muniarti. R., (2000). Segi Hukum Lembaga Keuangan dan Pembiayaan. Bandung: Citra Aditya Bakti.

Satrio, J. (2001). Hukum Perikatan, Perikatan Lahir Dari Perjanjian. Buku I. Bandung: Citra Aditya Bakti 


\section{AL-QISTH LAW REVIEW \\ VOL 5 NO. 1 (2021)}

Syahrani, R. (2013). Seluk-Beluk dan Asas-Asas Hukum Perdata. Bandung: Alumni.

Subekti. (2014). Aneka Perjanjian. Bandung: Citra Aditya Bakti, 2014.

Zaini, Z. D., Febriansyah, S. (2014) Aspek Hukum dan Fungsi Lembaga Penjamin Simpanan. Bandung: Keni Media.

Wibowo, P. (2013). Ancaman atau Kesempatan Bagi Perbankan Nasional" Pungky Purnomo Wibowo. Jakarta: Bank Indonesia. Diakses dari www.ni.go.id.

Iman, N. (2016). Financial Technology dan Lembaga Keuangan. Diakses tanggal 2 November 2018, Diakses dari financial-technology-lembagakeuangan.pdf (nofieiman.com).

Audriene, D., Nababan. C. N. (2016, April 19). OJK Waspadai Empat Risiko Bisnis Fintech. CNN Indonesia. Diakses dari OJK Waspadai Empat Risiko Bisnis Fintech (cnnindonesia.com)

Wijaya, R. (2016, Novermber 26). "P2P" Sebagai Wujud Baru Inklusi Keuangan. Kompas Online. Diakses dari "P2P Lending" sebagai Wujud Baru Inklusi Keuangan Halaman all - Kompas.com

Kusumasari, D. (2011). Surat Kuasa Khusus. Diakses Akses 8/03/2019. Dari http://www.hukumonline.com/klinik/detail/cl5976/ciri-dan-isi- 


\section{AL-QISTH LAW REVIEW}

VOL 5 NO. 1 (2021)

surat-kuasa-khusus.Timothy R. Lyman, Gautam Ivatury, adan Stefan Staschen.

(https://www.koinworks.com). 